\title{
Spawning behaviour and the softmouth trout dilemma
}

\author{
Manu Esteve, Deborah Ann McLennan, John Andrew Zablocki, Gašper Pustovrh, \\ Ignacio Doadrio
}

Received - 05 November 2013/Accepted - 26 February 2014. Published online: 30 June 2014; @Inland Fisheries Institute in Olsztyn, Poland Citation: Esteve M., McLennan D.A., Zablocki J.A., Pustovrh G., Doadrio I. 2014 - Spawning behaviour and the softmouth trout dilemma - Arch. Pol. Fish. 22: 159-165.

\begin{abstract}
Morphological, ecological and molecular data sets do not completely agree on the phylogenetic placement of the softmouth trout, Salmo (Salmothymus) obtusirostris (Heckel). Molecules posit that softmouths are closely related to brown trout, Salmo trutta L. while some morphological, ecological and life history traits place them in the most basal position of the Salmoninae subfamily between grayling (Thymallus) and lenok (Brachymystax). Here we add an additional source of data, behavioural characters based on the first reported observations of softmouth spawning. During spawning softmouth females present three important behaviours not found in the other Salmo members: they continually abandon their nests, rarely staying on them for periods over nine minutes; they expel different batches of eggs at the same nest at intervals of several minutes; and they do not cover their eggs immediately after spawning. These three behaviours are intriguing for two reasons: 1) they are possible homologous to behaviours found in grayling females; 2) when coupled to the
\end{abstract}

M. Esteve [ $\left.\Xi^{\circ}\right]$, I. Doadrio

Departamento de Biodiversidad y Biología Evolutiva

Museo Nacional de Ciencias Naturales

Jose Gutierrez Abascal 2, Madrid, Spain

e-mail: manu@mncn.csic.es

D.A. McLennan

Department of Ecology and Evolutionary Biology, University of

Toronto, 25 Willcocks St, Toronto, M5S 3G5 ON, Canada

J.A. Zablocki

Trout Unlimited, 720 Tahoe St STE 1, Reno NV 89509, USA

G. Pustovrh

University of Ljubljana, Biotechnical Faculty, Department of Animal

Science, Groblje 3, 1230 Domžale, Slovenia nest digging behaviour-widespread in all the salmonines, including softmouths, they seem to be mal-adaptive.

Keywords: phylogeny, spawning behavior, underwater video

\section{Introduction}

The softmouth trout, also known as the Adriatic trout, Salmo (Salmothymus) obtusirostris (Heckel), is a cold freshwater salmonid found naturally in only five river drainages of the Adriatic Sea: the Vrljika, Jadro and Krka in Croatia, the Neretva in Bosnia and Herzegovina and Croatia and the Zeta in Montenegro (Snoj et al. 2008). Based mainly on colour variations, it is sometimes divided into four subspecies: Salmothymus obtusirostris oxyrhynchus (Steindachner 1882) from the rivers Neretva and Vrljika (this study), S. o. salonitana (Karaman 1927) from the River Jadro, S. o. krkensis (Karaman 1927) from the River Krka and S. o. zetensis (Hadžišče 1961) from the River Zeta. Morphologically, the softmouth is deep bodied with relatively large scales. Its colouration includes various greens, pale yellows, and light browns with lateral round black and red spots with white outlines. Its most obvious morphological characteristic is an elongated snout and a small, fleshy subinferior mouth with small jaws and 
teeth. This distinct head morphology, which resembles the morphology of archaic salmonids such as grayling (Thymallus) and lenok Brachymystax lenok (Pallas), is responsible for its historically unstable classification. From its initial description as Salar obtusirostris by Heckel (1851), it was moved to Thymallus (Steindachner 1874) and Salmo (Steindachner 1882), before being placed in its own genus, Salmothymus (Berg 1908). Behnke (1968) later redefined the taxon as a subgenus of Salmo based on morphological characters, however a general consensus based on morphology has never been reached. For instance, Sanford (2000) based on an exhaustive osteological analysis of juvenile fish, unequivocally placed softmouth in the genus Salmo. While other authors, also basing their studies on osteological characters, placed it within the Salmothymus genus in the most basal position of the salmonine tree (Stearley and Smith 1993, Wilson and Li 1999). A molecular-based study by Snoj et al. (2002); see also Sušnik et al. (2006), placed the softmouth with the Ohrid trout, Salmo ohridanus (Steindachner) as the sister group to brown trout, Salmo trutta L., with a recommendation to move it into Salmo.

Several ecological and life history traits are not congruent with the new phylogenetic position of this species. For instance, softmouths spawn in late winter-early spring, which can be viewed as intermediate between traditional fall (Salmo) and spring (graylings and lenoks) spawners. Also like graylings they are benthic feeders and have a similar behavioural ecology usually spending their time in the middle of river and always swimming in small groups of at least two or three individuals (Georgiev 2003, Mrdak et al. 2012). Softmouths never rest on the ground between stones or plants as do brown trout, hiding only rarely, and then only in large cavities (J. Schoeffmann - personal communication). We have named this disagreement between molecules on one side and some morphology, ecology, and life history traits, on the other the "softmouth trout dilemma". Here we present data from yet another source, behaviour, to further investigate this dilemma. In this manuscript therefore, we ask what can spawning behaviour tell us about the evolutionary history of softmouth trout? We began by collecting information from video recordings of softmouth trout during spawning, which has never been reported before. We then discuss the results comparing softmouth trout spawning behaviour with the other Salmo members, in particular, and with the other salmonines, in general, to see whether this information could provide clues to resolving this dilemma.

\section{Materials and methods}

\section{Study Area}

The Neretva is a $230 \mathrm{~km}$ long karst river in the Dinaric Alps flowing through Bosnia and Herzegovina and joining the Adriatic Sea in Croatia. Underwater recordings took place in the upper Neretva during March 11, 2009 in a shallow gravel, area located approximately $2 \mathrm{~km}$ upstream from Glavatičevo village $(43.2952 \mathrm{~N}, 18.0843 \mathrm{E}, 381 \mathrm{~m}$ altitude). Recordings were made with a Sony HDR-HC7 video camera inside an underwater housing. The camera was placed approximately 0.7 meters from an active nest identified as an elliptical area with clean gravel containing at least one fish. Neretva softmouth trout presented no marked sexual dimorphism, so behaviour was used to infer sex: the fish that intermittently performing quivering (courtship behaviour consisting of low amplitude and high frequency body vibrations from head to tail) was identified as the male, while the female was the fish that regularly performed nest digging (female turns on her side and excavates a depression in the gravel by beats of her tail).

The Vrljika River originates northwest of the town Imotski in Croatia. After crossing the Croatian-Bosnian, the name of the river is Matica and it goes underground near the town of Drinovci. It comes out as the Tihaljina River, which is in its lower part known as the Trebižat River, the right tributary to the Neretva River. Observations in the Vrljika were made during February 13-15, 2011 and February 
7-10, 2013 in Proložac near Imotski (43.2712 N, 17. $1025 \mathrm{E}, 270 \mathrm{~m}$ altitude). The 2011 recordings were taken from the riverbank using a tripod and a Sony HDR-HC7 video camera. The 2013 recordings were done underwater using Gopro cameras (www.gopro.com) mounted on stationary underwater tripods. As in Neretva, the Vrlijika females did not show marked sexual dimorphism and behaviour was used to infer the sex.

\section{Results}

Three distinct behaviours respect to the other Salmo members studied were identified as follows:

1. Females make short and continuous visits to their nests (wandering).

2. Females perform several spawning acts in the same nest separated by only a few minutes.

3. Females do not cover their eggs immediately after spawning.

Details on each of the rivers are as follows:

Neretva 2011

One female was recorded continuously abandoning her nest. She stayed for short periods of time during which she performed a total of 32 digging

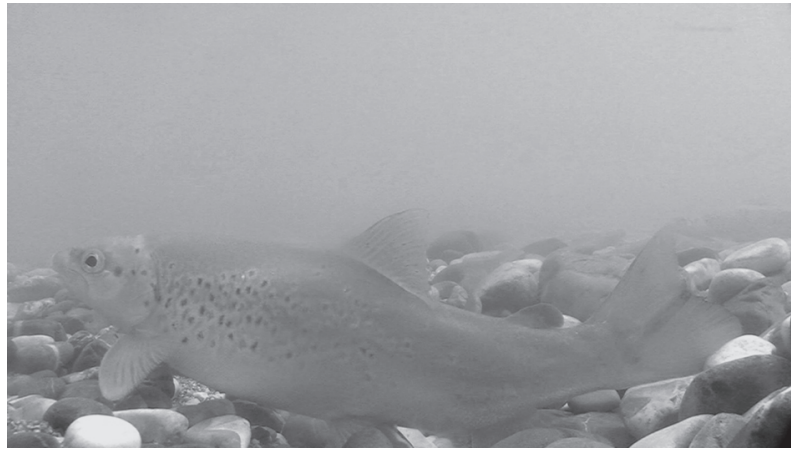

Figure 1. Female softmouth trout probing substrate with her anal fin.

episodes alternating with probing (the female lies over her nest and presses her anal fin into the substrate to test its suitability; Fig. 1). Nest residence time was not quantified because of interruptions caused by camera battery failure.

Vrlijika 2012

One female was recorded in the same redd being courted and guarded by the same male during three consecutive days, fot a total of 15 hours and 30 minutes of spawning activity (Table 1 ). The results confirmed the pattern of female periodic nest visits recorded in the Neretva. Recordings from February 13 included twelve spawning acts and are presented graphically in Fig. 2.
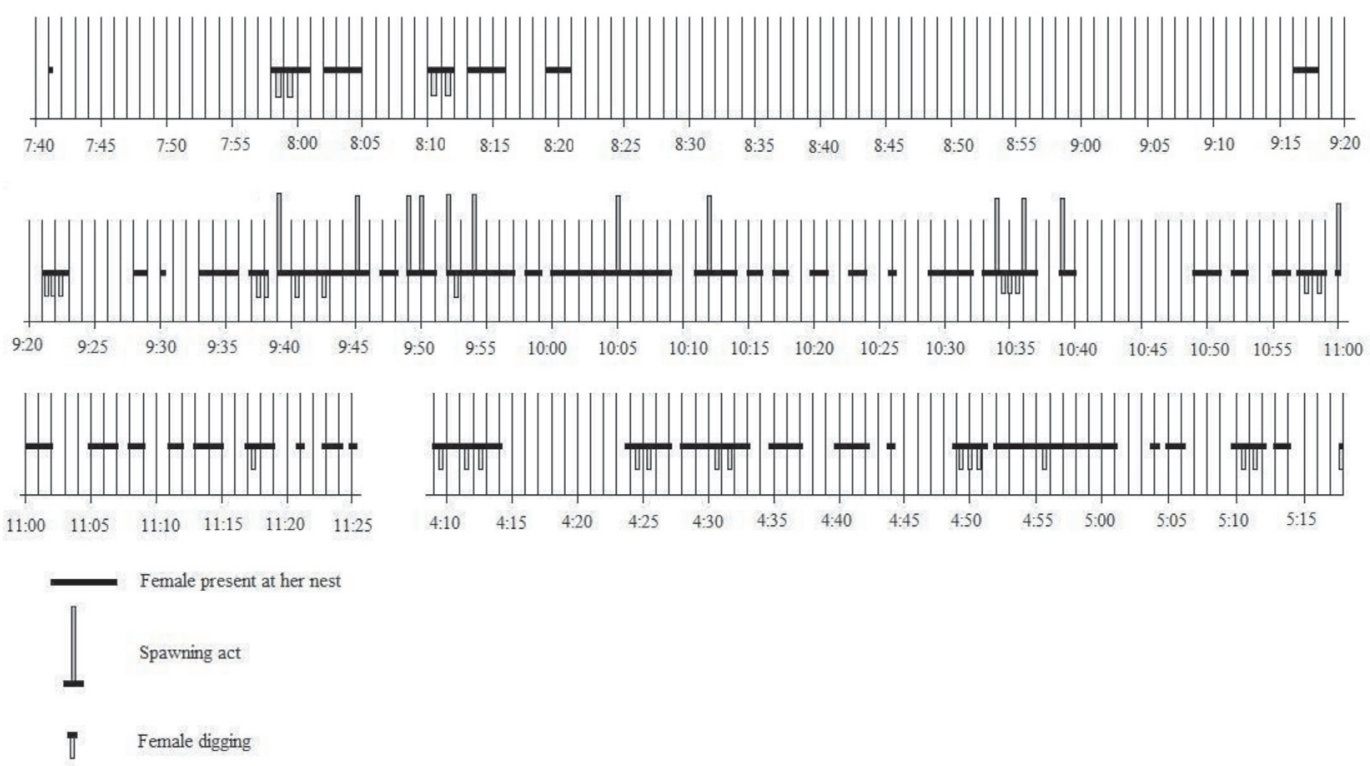

Figure 2. Ethogram of female softmouth trout activity at the Vrljika during February 13, 2011. 
Table 1

Recording history of one softmouth tout female in the 2011 Vrlijika River spawning season (time is expressed in minutes)

\begin{tabular}{|c|c|c|c|c|c|c|}
\hline & Rt & nt & $\mathrm{nv}$ & a nt & nd & $\mathrm{n} \mathrm{sp}$ \\
\hline Feb 12 & 258 & 22 & 7 & 3.14 & 3 & 0 \\
\hline Feb 13 & 587 & 125 & 54 & 2.33 & 32 & 12 \\
\hline Feb 1 & 85 & 30.5 & 6 & 5.07 & 14 & 0 \\
\hline Total & 930 & 177.5 & 67 & 2.65 & 49 & 12 \\
\hline
\end{tabular}

$\mathrm{Rt}$ - (recording time): minutes recorded, nt - (nesting time): minutes female spent at the nest, nv - (number of visits): number of nest visits by the female, a nt - (average nesting time): average time female spent at nest, nd - (number of digs): number of nest building digging episodes, $\mathrm{n} \mathrm{sp}$ - (number of spawnings): number of spawning acts performed by the female

Vrlijika 2013

Three females were recorded digging their nests while accompanied by a variable number of males. The wandering behaviour was confirmed in all the females. Nest residence time was only quantified for female 3. During the 123 minutes (min) recorded, female 3 left the nest on 21 occasions for a total absence time of $67 \mathrm{~min}$, with an average absent time of 3 min and $29 \mathrm{~s}(10: 51-12: 54, \mathrm{n}=21)$.

\section{Discussion}

\section{Spawning behaviour of softmouth trout}

Softmouth trout spawning behaviour resembles in general that of other salmonines. Females invest time building and testing their nests, while males invest theirs guarding and courting nesting females (Groot 1996). However, during spawning softmouths present at least three remarkable behavioural differences that need to be explained. Firstly, rather than staying in the nest area during the nest building period, softmouth females continuously abandoned the area in short periods of "stay and go" alternating with longer absences (wandering, Fig. 2). Secondly, they expelled several batches of eggs on the same nest separated by a few minutes' intervals. Finally, they did not cover their eggs immediately after spawning. These three behaviours are intriguing because they are not found in any other Salmo member studied. Furthermore, they are possibly homologous to behaviours found in grayling females, and when coupled with the nest digging behaviour, they seem to be mal-adaptive.

Building a nest in running waters requires hours of work; around 300 digging episodes are necessary to build depressions deep enough to bury eggs (Tautz and Groot 1975, Esteve 2005). Leaving a nest unattended, for even short periods of time, does not, therefore, seem to be adaptive as other females can deposit their eggs in it during the owner's absence. These females benefit directly because the energy they save by not building their own nest can be used for egg production, and indirectly, if they displace or destroy the nest builder's own eggs during spawning. Additionally, if the eggs have not been covered, as was noted in this study, a wandering softmouth female also runs the risk of egg predation when she is away from her nest. The only salmonids known to have a similar female behaviour are graylings. Grayling females make short visits to territories defended by males. During such visits the male will court then for a variable number of minutes (0.5-5), and then will either leave or expel a small batch of eggs and leave to repeat the process again some minutes later with or without the same male (Fabricius and Gustafson 1955, Beauchamp 1990, Darchambeau and Poncin 1997). Contrary than in the case of softmouth females grayling females do not build nests. Consequently, when they larvae, they do not pay extra costs of potential nest stealers, neither they have the risk of egg predation as the egg laying area is guarded by the territorial male, something that does not occur with softmouth trout males. 
Whether the unique wandering behaviour of softmouth females is homologous the grayling females is not yet clear; however no other species among the salmonines is reported to exhibit similar nest visiting behaviour.

The softmouth female observed spawning in this study performed twelve spawning acts at the same nest. In all salmonines, except the ones belonging to Salvelinus, the interval between successive spawning acts will last for several hours (Evans 1994, Fleming 1996). In Salvelinus successive spawnings separated by a few minutes can be understood as an adaptation to spawn in still waters since it is no necessary to cover eggs protect them from water currents immediately after spawning, females can partition spawning in small egg batches (Esteve et al. 2011). Grayling, on the contrary, as softmouth females spawn in running waters and also do perform sequential spawning. Based on observations of 72 spawning acts, Fabricius and Gustafson (1955) reported that Arctic grayling, Thymallus arcticus (Pallas), females had an average interval between spawning acts of $16.3 \mathrm{~min}(2-56$ $\mathrm{min}$ ), and the total number of spawning acts performed by a single female ranged from 18 to 34 . This figure is similar to the one found in our study (12 spawning acts; average interval $7.36 \mathrm{~min}$ ) and contrasts with the typical spawning interval of Salmo and Oncorhynchus females in which successive spawnings are typically 3-9 hours apart (Esteve 2005). Again, the similarity between softmouth and grayling females needs to be further researched to establish real homology; nevertheless, the fact that the diameter of softmouth trout eggs is intermediate between grayling and brown trout is probably related to this unique behaviour (Vuković and Ivanović 1971).

Of all the salmonine genera studied to date, only Parahucho, Oncorhynchus and Salmo females cover their eggs by beating their caudal fin immediately after spawning (Esteve et al. 2011). Softmouth females continued doing the same thing they were doing before spawning, lying on their nest and probing its conditions by pressing their anal fin into the gravel (Figs. 1 and 2). In three of the twelve spawnings acts recorded, the female did dig; however, those diggings cannot be considered as covering because they were performed at the center of the pit, which seems to be another maladaptive behavior (covering digs are always performed laterally from the upstream rim of the nest; Groot 1996, Quinn 2005), and they did not occur in the immediate seconds following spawning act. Grayling females neither cover their eggs after spawning, however, they are not nest builders and consequently whether this behaviour in both species is homologous again is not clear.

Regardless of whether softmouth behaviours are homologous to those of graylings, the behaviours reported above are indicative of two important facts. Firstly, they do not support the current classification of softmouths within Salmo. Secondly, when combined with nest digging behaviour, they seem to be maladaptive and raise the possibility of a distant intergeneric hybridization event. Snoj et al. (2002) suggested that the morphological and ecological similarities between softmouths and graylings, might stem from the retention of pleisiomorphic traits by a Salmo ancestor after colonizing and occupying an empty ecological niche in a restricted area of the western Balkans. That will require the genus Salmo to be the sister group of the reminder Salmoninae, and even if this is true, it fails to explain why Atlantic salmon, Salmo salar L., which diverged before softmouths and brown trouts do not have the grayling similarities. Furthermore, there are myriad of rivers with no graylings but with brown trouts and there are no reports of brown trout populations occupying the grayling niche in any of them. An alternative explanation also considered by Snoj et al. (2002) will be reversal evolution. Many biologists argue that evolutionary reversal is only likely on small time scales (e.g., within populations of the same species). Consequently, Snoj et al. (2002) recognized that is unlikely that softmouth redeveloped so many similar traits as graylings as a response to environmental adaptation.

If the answers to resolve the dilemma are not retentions or reversals of some pleisiomorphic traits, then the solution left may come by a complex history of hybridizations leading to genetic introgressions and/or reticulation evolution. Hybridization has been considered one of the major evolutionary 
mechanisms involving salmonids evolution (Scribner et al. 2000, Taylor 2004) and are known to have obscured the phylogenetic history of this group (Crespi and Fulton 2004, Wilson and Williams 2010, Crête-Lafrenière et al. 2012). In the Neretva, we witnessed several courting behaviours involving brown and softmouth trouts. Genetic introgression between both species has, in fact, been reported in the Neretva (Razpet et al. 2007) and a distant reticulation event has been detected in the Jadro (Sušnik et al. 2007). It is possible that these introgressions have been occurring repetitively during history and, thus, are responsible for the molecular similarities between both species. Although this explains why molecular analysis places them so close, it fails to explain the similarities between softmouths and graylings. For that it will be necessary distant genetic introgressions between Salmo and Thymallus ancestors. With all the information available to date there are no evidences for such events taking place (A. Snoj - personal communication).

\section{Conclusions}

Overall, spawning behaviour questions have promoted the recent taxonomic decision to move the softmouth trout from Salmothymus to Salmo. The behaviours we reported here are very probably indicating a complex evolutionary history in genetic introgressions have played a major role. Completely ruling out the possibility that these behaviours are homologous with those of graylings, requires exhaustive molecular analysis, and if this conclusion is finally to be reached, further research on the Salmo genus as a group must be conducted. Specifically, research on the spawning behaviour of Ohrid trout, $S$. ohridanus, which is a sister group of softmouths (Snoj et al. 2002, Sušnik et al. 2006) as well as with many other Salmo members whose behaviour remain unknown may clarify the evolution of softmouth spawning behaviour. The possibility of reversal evolution should then be reevaluated with a particular focus in species that live on lakes and, consequently, have had different selection pressures. Until then, we recommend to name the softmouth trout Salmo(thymus) obtusirostris unitil more data to resolve the evolutionary history of this enigmatic species.

Acknowledgments. We are most grateful to Armin Zonič and Xeno Tabakovič for assistance during the 2009 Neretva field season, to Ante Mikulič and Anita Mikulič for assistance during the 2011 and 2013 Vrlijika field seasons, to Ante Grbavac for assistance, to Zdenko Grbavac for placing the cameras underwater, and to Ivica Jurić Kaćunić for finding ME's submerged wheelchair in the Vrlijika during the 2013 field season, and to Mila Lončar, Gvido Piasevoli and Stjepan Mekinić for giving us permission to underwater record in the Vrlijika. The manuscript has been largely beneficiated by comments by Aleš Snoj and an anonymous reviewer. Funding was provided by research grants to D.A.M (NSERC Discovery Research Grant).

Author contributions. M.E. designed the study, participated in all the field work recordings, analyzed all the tapes and wrote the manuscript jointly with D.A.M. J.Z. performed the Neretva 2011 recordings with M.E. and provided comments to improve the manuscript. G.P. performed the Vrlijika 2012 recordings with M.E. and provided comments to improve the manuscript. I.D. provided comments to improve the manuscript.

\section{References}

Beauchamp D.A. 1990 - Movements, habitat use, and spawning strategies of Arctic grayling in a subalpine lake tributary - Northwest Sci. 64: 195-207.

Behnke R.J. 1968 - A new subgenus and species of trout, Salmo (Platysalmo) platycephalus, from southcentral Turkey, with comments on the classification of the subfamily Salmoninae - Mitt Hamburg Zool Mus Inst. 66: 1-15.

Berg L.S. 1908 - Vorläufige Bemerkungen über die europäischasiatischen Salmoninen, insbesondere die Gattung Thymallus - Ann. Mus. Zool, Acad. Sei. St. Petersbourg, 12: 500-514.

Crespi B.J., Fulton M. 2004 - Molecular systematics of Salmonidae: combined nuclear data yields a robust phylogeny - Mol. Phylo. Evol. 31:658-679.

Crĉte-Lafrenière A., Weir L.K., Bernatchez L. 2012 - Framing the Salmonidae Family Phylogenetic Portrait: A More 
Complete Picture from Increased Taxon Sampling - PLoS ONE 7(10): e46662. doi:10.1371/journal.pone.0046662.

Darchambeau F., Poncin P. 1997 - Field observations of the spawning behaviour of European grayling - J. Fish Biol. 51: 1066-1068.

Esteve M. 2005 - Observations of spawning behaviour in Salmoninae: Salmo, Oncorhynchus and Salvelinus - Rev. Fish Biol. Fish. 15: 1-21.

Esteve M., McLennan D.A., Kawahara M. 2011 - Spawning behaviour of amemasu charr, Salvelinus leucomaenis leucomaenis, with a discussion of the macroevolutionary patterns of post-spawning behaviour in the Salmoninae Ecol. Freshw. Fish. 20: 364-370.

Evans D.M. 1994 - Observations on the spawning behaviour of male and female adult sea trout, Salmo trutta L., using radiotelemetry - Fish. Manage. Ecol. 1: 91-105.

Fabricius E., Gustafson K.J. 1955 - Observations on the spawning behaviour of the grayling, Thymallus thymallus (L.) - Report of the Institute of Freshwater Research, Drottningholm 36: 75-103.

Fleming I.A. 1996 - Reproductive strategies of Atlantic salmon: ecology and evolution - Rev. Fish Biol. Fish. 6: 379-416.

Georgiev S.B. 2003 - On the origin of the Balkan Peninsula Salmonids - Ribarstvo 61: 147-174.

Groot C. 1996 - Salmonid life histories - In: Principles of Salmonid Culture (Eds.) W. Pennell, A. Bruce, Elsevier, Amsterdam, 97-230.

Hadžišče S. 1961 - Zur Kenntnis des Salmothymus ohridanus (Steindachner) (Pisces, Salmonidae) - Internationale Vereinigung für theoretische und angewandte Limnologie Verhandlungen 14: 785-791.

Heckel J.J. 1851 - Bericht einer ichthyologischen Reise. II Beiträge $\mathrm{zu}$ den Gattungen Salmo, Fario, Salar, Coregonus, Chondrostoma und Telestes - Sitzungsber. Akad. Wiss. Wien, 347-390.

Karaman S. 1927 - Les salmonidés des Balkans. Bull. . Soc. Sci. Skoplje - 2: 253-268.

Mrdak D., Nikolić V., Tošić A., Simonović P. 2012 - Molecular and ecological features of the soft-muzzled trout Salmo obtusirostris (Heckel, 1852) in the Zeta River, Montenegro - Biologia 67: 222-233.

Quinn T.P. 2005 - The Behavior and Ecology of Pacific Salmon and Trout - Univ. Washington Press, Seattle, WA, 328 p.

Razpet A., Sušnik S., Jug T., Snoj A. 2007 - Genetic variation among trout in the River Neretva basin, Bosnia and Herzegovina - J. Fish Biol. 70 (Suppl. A): 94-110.

Sanford C.P.J. 2000 - Salmonid fish osteology and phylogeny (Teleostei: Salmonoidei) - Theses Zoologicae, Koeltz Scientific Books, 264 p.
Scribner K.T., Page K.S., Bartron M.L. 2000 - Hybridization in freshwater fishes: a review of case studies and cytonuclear methods of biological inference - Rev. Fish Biol. Fish. 10: 293-323.

Snoj A., Melkič E., Sušnik S., Muhamedagić S., Dovč P. 2002 - DNA phylogeny supports revised classification of Salmothymus obtusirostris - Biol. J. Linn. Soc. 77: 399-411.

Snoj A., Bogut I., Sušnik S. 2008 - Evidence of a genetically distinct population of Vrljika softmouth trout Salmo obtusirostris Heckel evolved by vicariance - J. Fish Biol. 72: 1945-1959.

Stearley R.F., Smith G.R. 1993 - Phylogeny of the pacific trouts and salmons (Oncorhynchus) and genera of the family Salmonidae - Trans. Am. Fish. Soc. 122: 1-33.

Steindachner F. 1874 - Beschreibung einer neuen Art und Gattung aus der Familie der Pleuronectiden und einer neuen Thymallus-Art vor - Anzeiger der Akademie der Wissenschoften. Wien, 11: 171-172.

Steindachner F. 1882 - Ichthyologische Beiträge (XII) Sitzungsberrichte der Akademie der Wissenschoften, Wien, 61-82.

Sušnik S., Knizhin I., Snoj A., Weiss S. 2006 - Genetic and morphological characterization of a Lake Ohrid endemic, Salmo (Acantholingua) ohridanus with a comparison to sympatric Salmo trutta - J. Fish Biol. 68: 2-23.

Sušnik S., Weiss S., Odak T., Delling B., Treer T., Snoj A. 2007 - Reticulate evolution: ancient introgression of the Adriatic brown trout mtDNA in softmouth trout Salmo obtusirostris (Teleostei: Salmonidae) - Biol. J. Linn. Soc. 90: 139-152.

Tautz A.F. Groot C. 1975 - Spawning behavior of chum salmon (Oncorhynchus keta) and rainbow trout (Salmo gairdneri) - J. Fish. Res. Board Can. 32: 633-642.

Taylor E.B. 2004 - Evolution in mixed company - In: Salmon and their Relatives (Eds) A.P. Hendry, S.C. Stearns, Evolution Illuminated, Oxford University Press, Oxford, 232-263.

Vuković T., Ivanović B. 1971 - Slatkovodne ribe Jugoslavije Zemaljski muzej BiH, Sarajevo, 268 p.

Wilson M.V.H., Li G-Q. 1999 - Osteology and systematic position of the Eocene salmonid Eosalmo driftwoodensis Wilson from western North America - Zool. J. Linn. Soc. 125: 279-311.

Wilson M.V.H. Williams R.R.G. 2010 - Salmoniform fishes: key fossils, supertree, and possible morphological synapomorphies - In: Origin and phylogenetic interrelationships of Teleosts (Eds) J.S. Nelson, H.P. Schultze, M.V.H. Wilson, Verlag Dr. Friedrich Pfeil, München, Germany: 379-409. 